\title{
THE CURRENT SITUATION OF TRAINING STUDENTS MAJORING IN PHYSICAL EDUCATION AT CAN THO UNIVERSITY, VIETNAM
}

\author{
Nguyen Van Hoa', \\ Nguyen Huu Tri ${ }^{2}$ \\ ${ }^{1}$ Dr., Can Tho University, \\ Vietnam \\ ${ }^{2} \mathrm{MSc}$, Can Tho University, \\ Vietnam
}

\begin{abstract}
:
The objective of the research is to evaluate the training process for students majoring in physical education at Can Tho University in the period between 2004 and 2020. Through carefully examining and summarizing documents and surveys, the research accurately and comprehensively provides an overview of the current situation regarding the process of training physical education students at Can Tho University. The study looks at four issues: the enrollment process, graduation outcomes, graduates' employment situations, and employers' satisfaction level. The findings indicate that the enrolment process has been under difficulties regarding the number of enrolled students in recent years, the training quality is very good, students graduate on time, and the training products satisfy employers.
\end{abstract}

Keywords: training process, students majoring in physical education, Can Tho University.

\section{Introduction}

Can Tho University, the nation's important higher education institution in the Mekong Delta, is the cultural, scientific, and technical centre of the region. Its main missions are training, scientific research, and technology transfer for socio-economic development in the region. Can Tho University has a long history of development, dating back 55 years and currently having 14 years of training under the credit system. It is also a multidisciplinary training university: 19 doctoral training programs; 48 master training programs (01 foreign associate major and 03 majors using English language); and 109 undergraduate training programs (there are 2 advanced programs and 8 high-quality programs). Currently, it has an enrollment of about 51.609 students.

\footnotetext{
'Correspondence: vanhoa@ctu.edu.vn
} 
It was on that basis that the subject "physical education" was decentralized and managed by the party committee and Administrators Board of Can Tho University, with the role and missions of accomplishing the political tasks, such as: training students majoring in physical education and teaching non-specialized classes (1), developing staff (2), organizing and researching sports science (3), and organizing sports movements for staff and students in the university (4).

Currently, the enrollment process has undergone changes in both content and form. In particular, today's national entrance exams belong to the form " 3 trong 1" (collectively referring to the exam with three same characteristics: the same exam questions, same exam period, and same results), so urgent issues such as enrollment target, training quality, and especially graduates' employment situations, are always concerned by the Party, State, and People.

The Ministry of Education and Training issued Official Letter No. 4806/BGDĐT dated October 12, 2016 about: reporting the employment situation of graduates. Can Tho University has carried out surveys on graduates' employment situations, which are also considered an annual plan to approve enrollment quotas for full-time students. Due to the aforementioned issues, the paper conducted research on four issues: enrollment process, graduation outcomes, graduates' employment situations, and employers' satisfaction level, to evaluate "the current situation of training students majoring in physical education at Can Tho University."

The aim of the paper is to provide an overview accurately and comprehensively on training students majoring in physical education at Can Tho University in the period between 2004 and 2020 with four issues: the enrollment process, graduation outcomes, graduates' employment situations, and employers' satisfaction level. The findings are critically important in our understanding of finding solutions to enhance the quality of training students majoring in physical education at Can Tho University in the upcoming years.

\section{Material \& methods}

The research utilized the following methods: analyzing and summarize, interviews, and statistics.

Survey participants: 5 managers the department of physical education, Students Affairs Office, Office of academic affairs.

\section{Results}

\subsection{The current situation of enrollment process for physical education at Can Tho University}

Enrollment quotas, enrollment results, and entrance quality are important issues for all universities and colleges these days. Not only do they "determine" the survival and development of an educational institution, but they also evaluate the reliance or brand in 
the training process based on people's beliefs and options. Currently, Can Tho University has achieved success in the enrollment process and is ensuring $100 \%$ of the target approved by the Ministry of Education and Training. However, some majors, such as pedagogy and physical education, have a small number of applicants and thus fail to meet the enrollment quotas;

Table 1 indicates statistics of the enrollment process for physical education programs at Can Tho University run since 2004.

Table 1: Enrollment data for Group T (Mathematics, Biology, and Physical Education) in the physical education major at Can Tho University from 2004 to the present

\begin{tabular}{|l|c|c|c|c|c|}
\hline Year & $\begin{array}{c}\text { Academic } \\
\text { year }\end{array}$ & $\begin{array}{c}\text { Number of } \\
\text { candidates } \\
\text { who applied }\end{array}$ & $\begin{array}{c}\text { Number of } \\
\text { contestants }\end{array}$ & $\begin{array}{c}\text { Successful } \\
\text { candidates/targets } \\
\text { of the Ministry }\end{array}$ & $\begin{array}{c}\text { Acceptance } \\
\text { rates/targets }\end{array}$ \\
\hline 2004 & 30 & 960 & 705 & $47 / 40$ & $118 \%$ \\
\hline 2005 & 31 & 1.653 & 1.236 & $48 / 40$ & $120 \%$ \\
\hline 2006 & 32 & 1.438 & 1.136 & $67 / 60$ & $112 \%$ \\
\hline 2007 & 33 & 1.216 & 986 & $67 / 60$ & $112 \%$ \\
\hline 2008 & 34 & 1.187 & 934 & $78 / 80$ & $98 \%$ \\
\hline 2009 & 35 & 1.107 & 902 & $86 / 80$ & $108 \%$ \\
\hline 2010 & 36 & 1.137 & 917 & $80 / 80$ & $100 \%$ \\
\hline 2011 & 37 & 1.119 & 840 & $77 / 80$ & $96 \%$ \\
\hline 2012 & 38 & 1.120 & 805 & $87 / 80$ & $109 \%$ \\
\hline 2013 & 39 & 963 & 737 & $61 / 60$ & $102 \%$ \\
\hline 2014 & 40 & 848 & 611 & $64 / 60$ & $107 \%$ \\
\hline 2015 & 41 & 190 & 190 & $41 / 40$ & $103 \%$ \\
\hline 2016 & 42 & 98 & 98 & $39 / 40$ & $97,50 \%$ \\
\hline 2017 & 43 & 103 & 103 & $21 / 20$ & $100,5 \%$ \\
\hline 2018 & 44 & 155 & 93 & $19 / 33$ & $57,60 \%$ \\
\hline 2019 & 45 & 73 & 29 & $37 / 60$ & $61.67 \%$ \\
\hline 2020 & 46 & 96 & 39 & & \\
\hline
\end{tabular}

According to Table 1, there are two stages to the needs of candidates applying for admission to Group T (physical education major) at Can Tho University.

Stage 1: From 2004-2014, a large number of candidates applied and took the physical education exam (about 1000 candidates). The admissions results were favorable; some years reached over $100 \%$ (due to some candidates with the same score), and the admission rate is very highly competitive.

From 2015 to the present, the number of candidates has dropped dramatically (the highest needs were 190 in 2015, and the lowest needs were 73 in 2019). That is because the Ministry of Education and Training changed the way the university entrance exam was applied based on the form of using university entrance exams for university admissions. Furthermore, graduate students are increasingly having difficulty finding jobs, which has a significant impact on the number of candidates.

If plans for enrollment consulting and data on graduates' employment opportunities were lacking, the enrollment process for pedagogy and physical education 
would be extremely difficult in the future, and, more importantly, training for such majors may come to an end due to a lack of candidates.

\subsection{The graduation outcome of students majoring in physical education, Can Tho} University

Table 2 displays statistics on the graduation outcomes of students majoring in physical education at Can Tho University within the last six years.

Table 2: The graduation outcomes of students majoring in physical education at Can Tho University within the last six years

\begin{tabular}{|l|c|c|c|c|c|c|c|}
\hline \multirow{2}{*}{ Year } & \multirow{2}{*}{$\begin{array}{c}\text { Academic } \\
\text { year }\end{array}$} & \multicolumn{2}{c|}{$\begin{array}{c}\text { The number } \\
\text { of graduates }\end{array}$} & \multicolumn{5}{|c|}{$\begin{array}{c}\text { Graduation } \\
\text { outcomes }\end{array}$} \\
\cline { 3 - 8 } & & On time & Late & Outstanding & Excellent & Good & Average \\
\hline 2014 & 36 & 74 & 12 & 5 & 50 & 26 & 5 \\
\hline 2015 & 37 & 72 & 8 & 9 & 41 & 30 & 0 \\
\hline 2016 & 38 & 70 & 7 & 3 & 24 & 50 & 0 \\
\hline 2017 & 39 & 81 & 6 & 13 & 27 & 51 & 0 \\
\hline 2018 & 40 & 47 & 10 & 3 & 20 & 44 & 0 \\
\hline 2019 & 41 & 53 & 7 & 2 & 21 & 30 & 0 \\
\hline 2020 & 42 & 27 & 15 & 0 & 13 & 14 & 0 \\
\hline
\end{tabular}

Table 2 indicates that: a large number of students who graduate on time reach a high percentage; the reason for late graduation is that students have double majors or have not accumulated the required number of credits yet. The graduation outcomes mainly reached excellent and good levels, which comprised a high percentage. In the last three years, there has been no graduation outcome with an average level.

\subsection{Investigating the current situation of employment positions for students majoring} in physical education at Can Tho University in the period between 2016 and 2020

The Ministry of Education and Training issued Official Letter No. 4806/BGDĐT dated October 12, 2016 about: reporting the employment situation of graduate students. Can Tho University has carried out surveys on graduates' employment situations for all fulltime bachelor's training programs. Table 3 shows the research results for physical education. 
Table 3: The current situation of employment for graduates majoring in physical education at Can Tho University in the period between 2016 and 2020

\begin{tabular}{|c|c|c|c|c|c|c|c|c|c|}
\hline \multirow[b]{2}{*}{ ప్ర } & \multirow[b]{2}{*}{$\begin{array}{c}\text { Number } \\
\text { of } \\
\text { graduates }\end{array}$} & \multicolumn{3}{|c|}{$\begin{array}{c}\text { Employment } \\
\text { Situation }\end{array}$} & \multirow[b]{2}{*}{$\begin{array}{l}\text { Employment } \\
\text { rate of } \\
\text { students }\end{array}$} & \multicolumn{4}{|c|}{$\begin{array}{l}\text { Employment } \\
\text { Sector }\end{array}$} \\
\hline & & 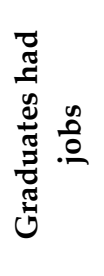 & 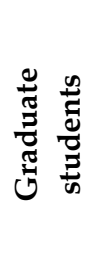 & 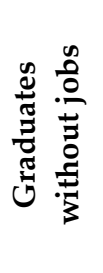 & & 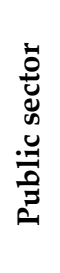 & 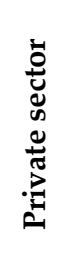 & 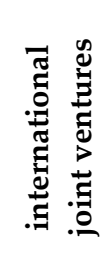 & 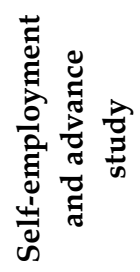 \\
\hline 2016 & 74/79 & 51 & 0 & 23 & $68,91 \%$ & 31 & 10 & 07 & 03 \\
\hline 2017 & $69 / 70$ & 61 & 06 & 02 & $97.1 \%$ & 25 & 21 & 06 & 09 \\
\hline 2018 & $63 / 63$ & 61 & 02 & 0 & $100 \%$ & 23 & 26 & 06 & 08 \\
\hline 2019 & $48 / 48$ & 48 & 0 & 0 & $100 \%$ & 19 & 17 & 06 & 06 \\
\hline 2020 & $67 / 70$ & 59 & 06 & 02 & $97.01 \%$ & 18 & 24 & 07 & 04 \\
\hline
\end{tabular}

Based on the results of employment positions through 4 years, Table 3 shows that there are $100 \%$ of graduates participating in surveys carried out by the Department of Physical Education at Can Tho University. In particular, 68,91\% of the class of 2016 graduates and $97,01 \%$ of the class of 2017 and 2020 graduates got jobs. $100 \%$ of the class of 2018 and 2019 candidates had jobs within six months of graduation. The majority of graduates had jobs that were suitable for the field of their training programs (Physical Education). A large number of graduates worked in the private sector, a few held positions in international joint ventures, and some created jobs on their own.

Therefore, Table 4 shows that most physical education graduates had jobs in the current period.

\subsection{The current situation of employers' satisfaction level}

Table 4 shows the results of evaluating the satisfaction level of employers with graduates majoring in physical education at Can Tho University; survey results with 30 high school teachers, specialists, and managers in the departments of Culture, Sports, and Tourism; Sports Centers; through the process of organizing scientific research seminars; leading student groups to do practicums and internships in pedagogy in Mekong River Delta.

Table 4: The results of the survey on employers' satisfaction level

\begin{tabular}{|c|l|c|c|c|c|c|c|}
\hline \multirow{2}{*}{ No. } & \multirow{2}{*}{ Content survey } & \multicolumn{4}{|c|}{ Results } \\
\cline { 3 - 8 } & & \multicolumn{2}{|c|}{$\begin{array}{c}\text { Extremely } \\
\text { satisfied }\end{array}$} & \multicolumn{2}{|c|}{ Satisfied } & \multicolumn{2}{|c|}{ Unsatisfied } \\
\cline { 2 - 9 } & $\mathbf{n}$ & $\mathbf{\%}$ & $\mathbf{n}$ & $\mathbf{\%}$ & $\mathbf{n}$ & $\%$ \\
\hline 1 & $\begin{array}{l}\text { Graduates' knowledge that meets } \\
\text { the job position }\end{array}$ & 16 & 44.44 & 18 & 50.00 & 2 & 5.56 \\
\hline 2 & Graduates' employability skills & 17 & 41.67 & 19 & 52.78 & 2 & 5.56 \\
\hline 3 & Graduates' work attitude & 14 & 38.89 & 20 & 48.00 & 2 & 5.56 \\
\hline 4 & $\begin{array}{l}\text { The ability to organize professional } \\
\text { activities }\end{array}$ & 12 & 33.33 & 18 & 38.12 & 6 & 16.67 \\
\hline 5 & Scientific research ability & & & & & &
\end{tabular}




\begin{tabular}{|c|l|c|c|c|c|c|c|}
\hline \hline 6 & $\begin{array}{l}\text { The ability to coordinate with colleagues } \\
\text { and with superiors }\end{array}$ & 17 & 47.22 & 18 & 46.29 & 1 & 2.78 \\
\hline 7 & $\begin{array}{l}\text { The ability to adjust to employment } \\
\text { in the integration period }\end{array}$ & 13 & 36.11 & 18 & 54.00 & 5 & 13.89 \\
\hline
\end{tabular}

According to Table 4, most employers are extremely satisfied and satisfied with graduates majoring in physical education, reaching $83.33 \%$ to $97.2 \%$, and less employers evaluate unsatisfied. However, it is essential to direct attention to two issues: the ability to conduct scientific research and the ability to adjust to employment in the integration period, because students have limited conditions to access scientific research and foreign language classes

\section{Conclusions}

According to the research on the current situation of training students majoring in physical education at Can Tho University, I conclude that:

- In the enrollment process from 2004-2014, the number of candidates applying and participating in physical education was very large, the enrollment outcomes were very favorable, and enrollment met the quota. From 2015 to the present, the number of candidates has dropped dramatically, and the enrollment process has captured difficult conditions, which merely reached $57.6 \%$ of the target approved by the Ministry of Education and Training in 2019.

- A large number of students who graduate on time reach a high percentage; students with late graduation is that they had to have double majors or have not accumulated the required number of credits yet.

- Most physical education graduates have jobs in the current period.

- Most employers are extremely satisfied and satisfied with graduates majoring in physical education, reaching $83.33 \%$ to $97.2 \%$. However, in order to meet the professional needs of today's integration period, it is also necessary to focus on encouraging students to participate in scientific research and learn more foreign languages.

\section{Conflict of Interest Statement}

The authors declare no conflicts of interests.

\section{About the Authors}

Nguyen Van Hoa has been a physical education teacher at Can Tho University, Vietnam. Nguyen Huu Tri has been a physical education teacher at Can Tho University, Vietnam. 


\section{References}

1. Ministry of Education and Training (2016), Official Letter No. 4806/BGD\&ĐT-GDĐH V/v Report on Graduates' Employment Situation.

2. Ministry of Education and Training (2016), Official Letter No: 796/BGDĐT of the Ministry of Education and Training: Guidelines for full-time teacher training program enrollment in regular universities, junior colleges, and vocational schools in 2019.

3. Government (2014), Resolution No. 44/NQ-CP dated June 9, 2014 on the implementation of Resolution No. 29/NQ-TW dated November 4, 2013 at the 8th Conference of the Central Committee, term XI on fundamentally and comprehensively innovating education and training, Ministry of Education and Training.

4. Can Tho University (2016) Official Dispatch No. 2173/ĐHCT- ĐBCCL\&KT dated October 21, 2016 on making conclusions and assigning tasks to the survey and reporting on survey results and ensuring proof requirements for survey implementation. 

be applied to their work. Under the terms of this license, no permission is required from the author(s) or publisher for members of the community to copy, distribute, transmit or adapt the article content, providing a proper, prominent and unambiguous attribution to the authors in a manner that makes clear that the materials are being reused under permission of a Creative Commons License. Views, opinions and conclusions expressed in this research article are views, opinions and conclusions of the author(s). Open Access Publishing Group and European Journal of Physical Education and Sport Science shall not be responsible or answerable for any loss, damage or liability caused in relation to/arising out of conflict of interests, copyright violations and inappropriate or inaccurate use of any kind content related or integrated on the research work. All the published works are meeting the Open Access Publishing requirements and can be freely accessed, shared, modified, distributed and used in educational, commercial and non-commercial purposes under a Creative Commons attribution 4.0 International License (CC BY 4.0). 